\title{
BAKTI KESEHATAN PADA LANJUT USIA DI SASANA TRESNA WERDHA RIA PEMBANGUNAN CIBUBUR
}

\author{
Noer Saelan Tadjudin ${ }^{1}$, Ananda Putra ${ }^{2}$ \\ ${ }^{1}$ Departemen Kesehatan Jiwa, Universitas Tarumanagara Jakarta \\ Email: Email:noert@fk.untar.ac.id \\ ${ }^{2}$ Program Studi Pendidikan Dokter, Universitas Tarumanagara Jakarta \\ Email: Ananda.putra098@gmail.com
}

\begin{abstract}
Elderly groups, including the elderly in nursing homes, are vulnerable to transmission of Covid-19, so efforts are needed to improve the health of the elderly in nursing homes through health promotion, namely counseling related to clean and healthy lifestyles. Counseling activities at the Tresna Werdha Ria Development Center of Cibubur during the Covid 19 pandemic are rarely carried out and the Faculty of Medicine of Tarumanagara University is collaborating with the Tresna Werdha Ria Development Center of Cibubur in the learning process of Geriatric clinical clerkship students. Healthy and Clean Life Behavior in the elderly who live in Sasana Tresna Werdha Ria Pembangunan Cibubur. This health service activity is carried out with the aim that the elderly at Sasana Tresna Werdha Ria Pembangunan Cibubur know about PHBS and have an impact on the implementation of PHBS in their daily lives. The introduction of PHBS counseling for the elderly at Sasana Tresna Werdha Ria Cibubur development is a series of health service activities that have been well organized on Saturday, October 16, 2021. The activity is carried out offline which stipulates implementing health protocols in its implementation, attended by 60 participants. Counseling related to PHBS is important and the application of Clean and Healthy Living Behavior needs to be considered in daily life, so that further health service activities are needed to assess that counseling participants have increased insight regarding clean living behavior and the stages of hand washing.
\end{abstract}

Keywords: elderly, PHBS, counselling

ABSTRAK
Kelompok lanjut usia termasuk lansia pada Panti Werdha rentan terhadap penularan Covid-19 maka perlu upaya untuk meningkatkan kesehatan lansia di Panti Werdha melalui promosi kesehatan yaitu penyuluhan terkait Perilaku Hidup Bersih dan Sehat. Kegiatan penyuluhan di Sasana Tresna Werdha Ria Pembangunan Cibubur selama pandemi Covid 19 jarang dilakukan serta Fakultas Kedokteran Universitas Tarumanagara bekerja sama dengan Sasana Tresna Werdha Ria Pembangunan Cibubur dalam proses pembelajaran mahasiswa kepaniteraan klinik Geriatri, maka tim pengabdian fakultas kedokteran Universitas Tarumanagara melakukan bakti kesehatan dengan penyuluhan mengenalkan Perilaku Hidup Sehat Dan Bersih pada lansia yang menetap di Sasana Tresna Werdha Ria Pembangunan Cibubur. Kegiatan bakti kesehatan ini dilakukan dengan tujuan lansia di Sasana Tresna Werdha Ria Pembangunan Cibubur mengetahui tentang PHBS serta berdampak penerapan PHBS dikehidupan sehari-hari. Pengenalan tentang penyuluhan PHBS pada lansia di Sasana Tresna Werdha Ria Pembangunan Cibubur merupakan rangkaian dari kegiatan bakti kesehatan telah terselenggara dengan baik pada hari Sabtu 16 Oktober 2021. Kegiatan dilakukan secara luring yang tetapkan menerapkan protokol kesehatan dalam pelaksanaannya dihadiri 60 peserta. Penyuluhan terkait PHBS penting dilakukan serta penerapan tentang Perilaku Hidup Bersih dan Sehat perlu diperhatikan dalam kehidupan sehari-hari, sehingga perlunya kegiatan pengabdian kesehatan selanjutnya untuk menilai bahwa peserta penyuluhan telah bertambah wawasan terkait perilaku hidup bersih serta tahapan cuci tangan.

Kata kunci: lansia, PHBS, penyuluhan

\section{PENDAHULUAN}

Berdasarkan penggelompokkan usia maka seorang lansia dibagi menjadi kelompok usia pertengahan atau middle age dari usia 49-59 tahun, usia lanjut mulai dari usia 60-70 tahun , kelompok usia tua atau old mulai dari 71-90 tahun dan kelompok usia sangat tua atau very old adalah seseorang dengan usia 90 tahun keatas . (Ouchi et al., 2017).

Bertambahnya jumlah kelompok penduduk lanjut usia merupakan hal yang tidak dapat dihindarkan, karena sebagian besar dari mereka pada dekade ini masih tergolong dalam usia 
produktif tetapi 5-10 tahun yang akan datang maka mereka tergolong lanjut usia. Perkembangan lansia bertambah pesat juga terjadi di Indonesia, persentasi lansia tahun 2020 sebesar 9,92\% atau 26,82 juta tergolong dalam lanjut usia. Indonesia mengalami fase terjadinya transisi kekeadaan masyarakatnya menuju proses penuaan, sehingga Indonesia sedang menuju ke fase struktur penduduk tua atau aging population. (Badan Pusat Statistik,2020), (Badan Pusat Statistik,2019)

Seiring meningkatnya populasi lanjut usia di Indonesia di masa yang akan datang memberikan pengaruh yang positif, yaitu lansia yang sehat serta produktif, tetapi semakin berrtambahnya jumlah lansia dapat menjadi beban saat lansia mengalami gangguan kesehatan terutama masa pandemi yang belum selesai sampai saat ini. Keparahan serta kematian akibat terinfeksi virus Covid-19 paling banyak terjadi pada kelompok lanjut usia. (LIPI,2020). Lansia pada Panti Werdha juga rentan terhadap penularan Covid-19 maka perlu upaya untuk meningkatkan kesehatan lansia di Panti Werdha. Promosi kesehatan terkait Perilaku Hidup Bersih dan Sehat adalah salah satu upaya meningkatkan kesehatan di Panti Werdha. (Kemenkes,2020)

Kegiatan penyuluhan di Sasana Tresna Werdha Ria Pembangunan Cibubur selama pandemi Covid 19 jarang dilakukan serta Fakultas Kedokteran Universitas Tarumanagara bekerja sama dengan Sasana Tresna Werdha Ria Pembangunan Cibubur dalam proses pembelajaran mahasiswa kepaniteraan klinik Geriatri, maka tim pengabdian fakultas kedokteran Universitas Tarumanagara melakukan bakti kesehatan dengan penyuluhan mengenalkan Perilaku Hidup Sehat Dan Bersih pada lansia yang menetap di Sasana Tresna Werdha Ria Pembangunan Cibubur. Kegiatan bakti kesehatan ini dilakukan dengan tujuan lansia di Sasana Tresna Werdha Ria Pembangunan Cibubur mengetahui tentang PHBS serta berdampak penerapan PHBS dikehidupan sehari-hari.

\section{METODE PELAKSANAAN PKM}

Pelaksanaan bakti kesehatan di Sasana Tresna Werdha Ria Pembangunan Cibubur tentang Perilaku Hidup Bersih dan Sehat (PHBS) Rumah Tangga dengan cara penyuluhan memberikan edukasi, gambaran serta kiat kiat penting terkait PHBS. Sasaran kegiatan penyuluhan adalah lansia beserta staff petugas yang berada di Sasana Tresna Werdha Ria Pembangunan Cibubur.

Rangkaian kegiatan dalam bakti kesehatan adalah :

1. Sosialisasi : Tim pengabdian menentukan tema penyuluhan yaitu PHBS dan berkoordinasi dilakukan oleh tim pengabdian dengan Pimpinan/kepala pihak Sasana Tresna Werdha Ria Pembanguna

2. Perumusan solusi : Hasil dari pertemuan dengan pimpinan Sasana Tresna Werdha Ria Pembangunan Cibubur ditetapkan kegiatan 16 Oktober 2021 untuk pelaksanaan yang dilakukan secara luring.

3. Materi Penyuluhan kesehatan pada lansia di Panti Werdha terkait PHBS serta dilakukan pemutaran video tentang Langkah cuci tangan

\section{HASIL DAN PEMBAHASAN}

Sasana Tresna Werdha Ria Pembangunan terletak di Jalan Pusdika, RT. 8, RW. 7, Cibubur, Kec. Ciracas, Kota Jakarta Timur, Daerah Khusus Ibukota Jakarta 13720 (Lihat gambar 1). Bangunan Sasana Tresna Werdha Karya Bhakti Ria Pembangunan mempunyai 3 lantai dan jumlah lansia yang berada di Sasana Tresna Werdha Ria Pembangunan sebanyak 65 lansia. 


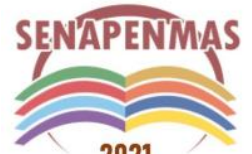

2021

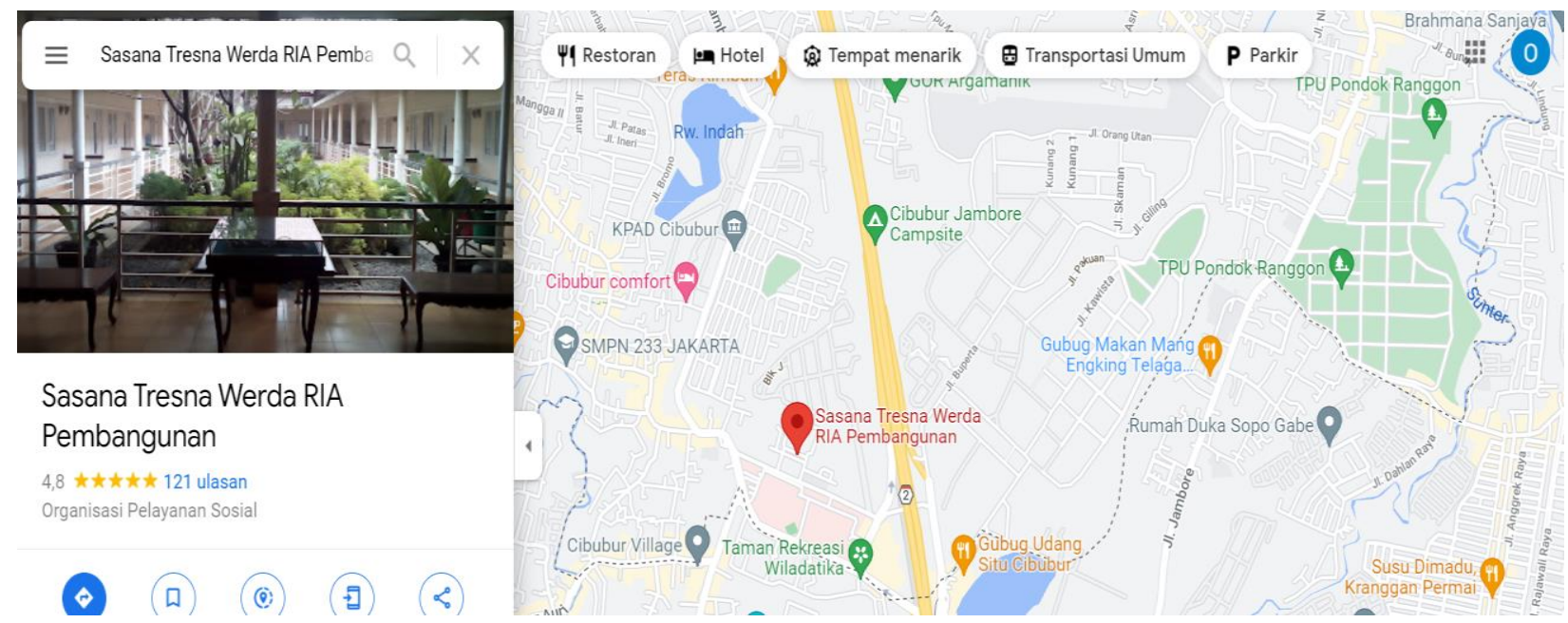

Gambar 1

Peta lokasi Sasana Tresna Werdha Ria Pembangunan

Kegiatan bakti kesehatan di Sasana Tresna Werdha Ria Pembangunan Cibubur dilakukan tanggal 16 Oktober 2021. Kegiatan bakti kesehatan dengan penyuluhan PHBS dilakukan secara luring diikuti sekitar 60 peserta yang terdiri dari lansia serta staff petugas di Sasana Tresna Werdha Ria Pembangunan Cibubur .

Susunan Acara kegiatan adalah :

09.00: Pembukaan

Sambutan dari STW - Pak Abbas

Sambutan dari Ketua pelaksana

09.20: Penyuluhan PHBS dan pemutaran video "Mencuci Tangan 6 Langkah"

09.35: Sesi tanya jawab oleh Opa dan Oma

09.45: Praktik Bersama Opa Oma melakukan cuci tangan yang benar

09.50: Penutupan + pembagian snak \& souvenir

Panitia tim pengabdian yang terlibat pada acara bakti kesehatan adalah

1. Dr. dr. Noer Saelan Tadjudin, Sp.KJ , Dekan Fakultas Kedokteran Universitas Tarumanagara

2. Ketua Pelaksana : Attalarick Gian Rahadi

3. Wakil Ketua : Sri Deasy Aryeni

4. Sekretaris : Shania Latiza

5. Acara\&kreatif : Koordinator - Wahyu Eka, Shaputri Chanelia Dirgatni Liow, Eirene Priscilla Caroline, Tri Yunita Alicia

6. Dokumentasi : Koordinator - Jason Kurnia, Angel Felisia

7. Humas : Koordinator - Ananda Putra

8. Logistik : Koordinator — Jodi David Christian, Thian Su

Tim penyuluh pada kegiatan bakti kesehatan menyampaikan materi penyuluhan terkait PHBS yaitu teknik mencuci tangan 6 langkah dengan tepat yaitu mencuci tangan dengan sabun di air mengalir. Materi kegiatan dapat dilihat pada gambar 1. Tim pengabdian memamparkan bahwa opa dan oma juga harus tetap menjaga kebersihan diri seperti mandi, menggosok gigi, berpakaian rapi dan bersih, menggunting kuku, serta menjaga kebersihan rambut, kuku dan kaki. Tim pengabdian mengajak peserta penyuluhan untuk mengatur pola makan, tetap beraktivitas fisik dan berolahraga menggunakan sarana di Sasana Tresna Panti Werdha Ria Pembangunan 
Cibubur, tetap bersosialisasi tetapi memperhatikan protokol kesehatan dan tetap berdoa. Tim pengabdian melakukan pemutaran video tentang "Mencuci tangan 6 langkah", peserta juga ikut mempraktekkan teknik cuci tangan dengan semangat. Kegiatan penyuluhan yang dilakukan secara luring tetap menerapkan protokol kesehatan yaitu memakai masker dengan tepat serta duduk antara peserta diberi jarak sesuai anjuran. Acara kegiatan dapat dilihat pada gambar 2.

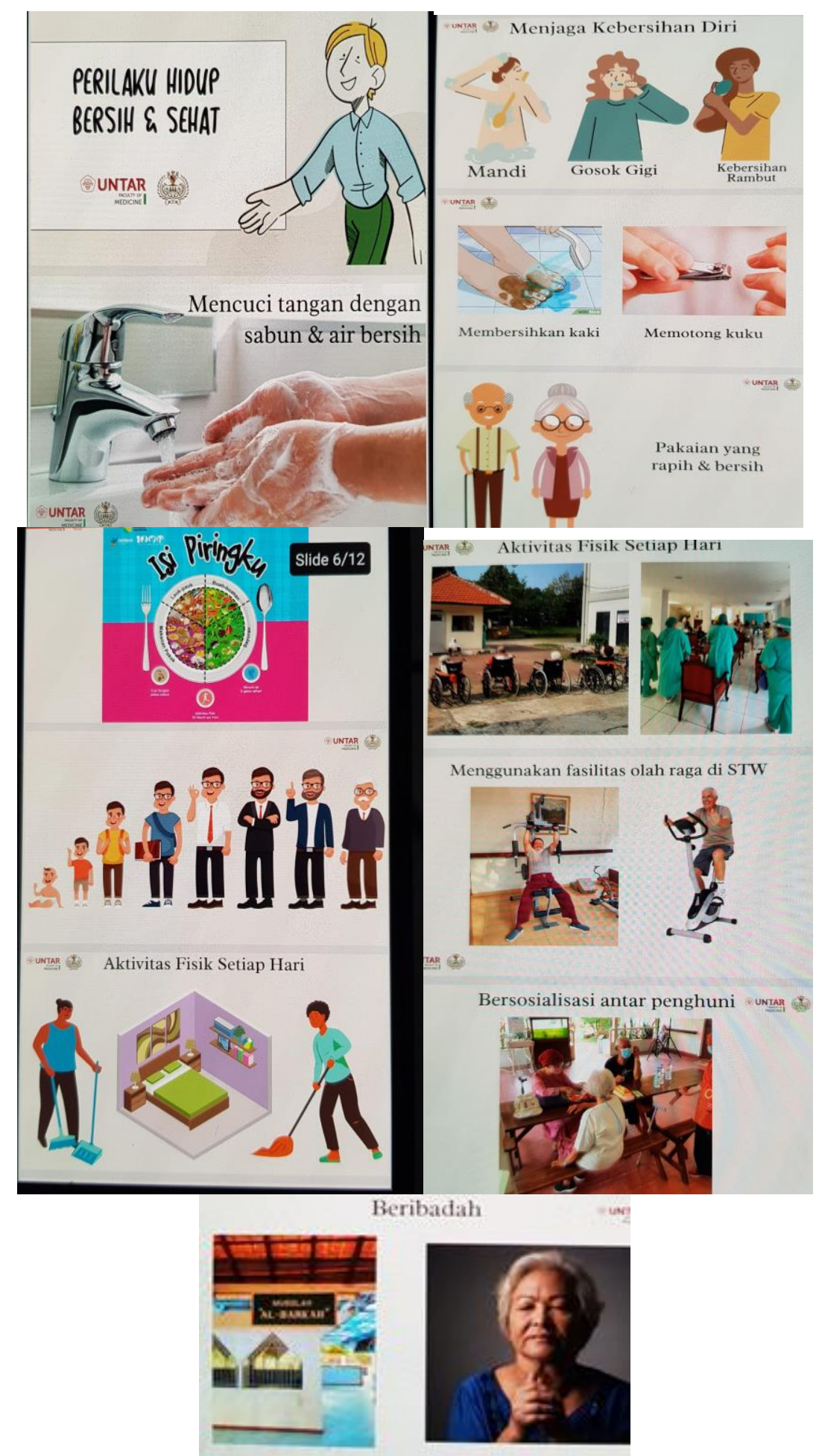

Gambar 2. Materi penyuluhan PHBS 


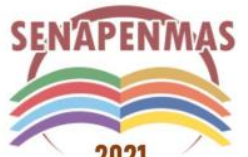

2021
Seminar Nasional Hasil Penelitian dan Pengabdian Kepada Masyarakat 2021

Pengembangan Ekonomi Bangsa Melalui Inovasi Digital Hasil Penelitian dan Pengabdian Kepada Masyarakat Jakarta, 21 Oktober 2021

Dalam kondisi pandemi ini, penerapan tentang Perilaku Hidup Bersih dan Sehat perlu dilakukan. PHBS merupakan kumpulan dari perilaku hidup bersih dan sehat yang nantinya dipraktikan dengan kesadaran sendiri sehingga mampu mandiri dalam menjaga kesehatan serta ikut serta meningkatkan derajat kesehatan masyarakat (Depkes RI, 2012).

Penerapan Perilaku Hidup Sehat Dan Bersih pada lansia adalah bagian dari program Gerakan Masyarakat Hidup Sehat (GERMAS) yang diterapkan oleh pemerintah. Peningkatan pengetahuan PHBS pada lanjut usia adalah upaya agar lansia dapat mandiri, tidak bergantung dengan orang lain serta mampu menjaga kesehatan serta kebersihan dirinya agar terhindar dari paparan penyakit. (Kauman, 2019).

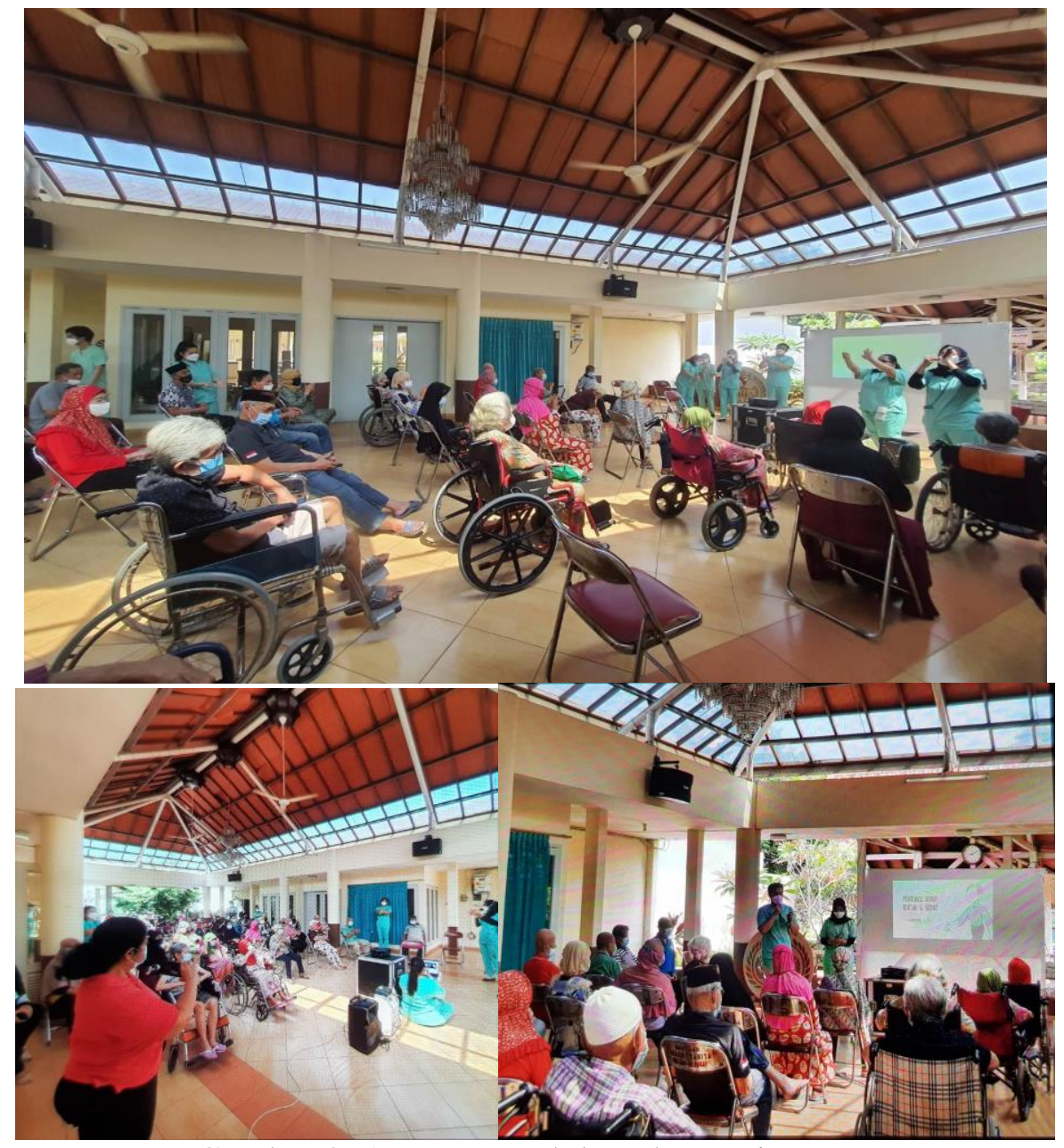

Gambar 3. Acara penyuluhan dan cuci tangan

Dengan pengenalan perilaku hidup bersih dan sehat khususnya pada lansia pada peserta penyuluhan dapat bertambah wawasan tentang PHBS serta mengenal tahapan cuci tangan, maka peserta penyuluhan yaitu lansia di Sasana Tresna Werdha Ria Pembangunan Cibubur mampu menolong dirinya dengan menjaga kesehatan dengan melakukan dan menerapkan PHBS di kehidupan sehari-hari.

\section{KESIMPULAN DAN SARAN}

Pengenalan tentang penyuluhan PHBS pada lansia di Sasana Tresna Werdha Ria Pembangunan Cibubur merupakan rangkaian dari kegiatan bakti kesehatan telah terselenggara dengan baik 
pada hari Sabtu 16 Oktober 2021. Kegiatan dilakukan secara luring yang tetapkan menerapkan protokol kesehatan dalam pelaksanaannya dihadiri 60 peserta. Penyuluhan terkait PHBS penting dilakukan serta Penerapan tentang Perilaku Hidup Bersih dan Sehat perlu diperhatikan dalam kehidupan sehari-hari, sehingga perlunya kegiatan pengabdian kesehatan selanjutnya untuk menilai bahwa peserta penyuluhan telah bertambah wawasan terkait perilaku hidup bersih serta tahapan cuci tangan.

\section{Ucapan Terima Kasih (Acknowledgement)}

Ucapan terima kasih tim pengabdian ucapkan kepada di Sasana Tresna Werdha Ria Pembangunan Cibubur atas bantuan dan dukungannya sera seluruh panitia acara dan peserta yang telah mengikuti kegiatan bakti kesehatan ini, sehingga kegiatan dapat terlaksana dengan baik dan lancar. Terima kasih juga kepada Panitia SENAPENMAS yang sudah memberikan kesempatan untuk berpatisipasi pada kegiatan SENAPENMAS 2021.

\section{REFERENSI}

Badan Pusat Statistik. (2019). Statistik Penduduk Lanjut Usia 2019. Jakarta: Badan Pusat Statistik.

https://www.bps.go.id/publication/2019/12/20/ab17e75dbe630e05110ae53b/statistikpenduduk-lanjut-usia-2019.html

Badan Pusat Statistik. (2020). Statistik Penduduk Lanjut Usia. Jakarta : Badan Pusat Statistik. https://www.bps.go.id/publication/download.html?nrbvfeve=MGZjMDIzMjIxOTY1NjI0Y TY0NGMxMTEx\&xzmn=aHR0cHM6Ly93d3cuYnBzLmdvLmlkL3B1YmxpY2F0aW9u LzIwMjAvMTIvMjEvMGZjMDIzMjIxOTY1NjIOYTY0NGMxMTExL3N0YXRpc3Rpay 1wZW5kdWR1ay1sYW5qdXQtdXNpYS0yMDIwLmh0bWw\%3D\&twoadfnoarfeauf=Mj AyMS0xMC0xNyAxOToxNjo0MA\%3D\%3D

BAPPENAS. (2019). Transisi Demografi dan Epidemiologi: Permintaan Pelayanan Kesehatan di Indonesia.

Jakarta:

BAPPENAS

https://www.bappenas.go.id/files/8515/9339/1872/FA_Preview_HSR_Book01.pdf

Kauman, P., Wijirejo, D., Wahyuningsih, I., Wahyuningtyas, W., Sari, D., Widyastuti, O., Dahlan, U. A., \&Prof, J. (2019). Pendampingan gerakan masyarakat hidup sehat Di Padukuhan Kauman, Bajang, Ngeblak, Desa Wijirejo, Pandak, Bantul. 3(1), 61-72.

Kemenkes. (2020). Panduan Pelayanan Kesehatan Lansia Era Covid 19 https://kesga.kemkes.go.id/assets/file/pedoman/Panduan\%20Pelayanan\%20Kesehatan\%20 Lansia\%20Era\%20Covid19.pdf

Kementerian Kesehatan RI. (2012). Peraturan Menteri Kesehatan Republik Indonesia Nomor: 2269/Menkes/ Per/XI/2011 tentang Pedoman Pembinaan Perilaku Hidup dan Sehat (PHBS). Pusat Promosi Kesehatan Sekretaris Jenderal Kementerian Kesehatan RI. https://promkes.kemkes.go.id/pub/files/files13583Pedoman_umum_PHBS.pdf

LIPI. (2020). Lansia dalam Pandemi Covid. https://kependudukan.lipi.go.id/id/berita/53mencatatcovid19/847-lansia-dalam-situasi-pandemi-covid-19

Ouchi, Y., Rakugi, H., Arai, H., Akishita, M., Ito, H., Toba, K., \& Kai, I. (2017). Redefining the elderly as aged 75 years and older: Proposal from the Joint Committee of Japan Gerontological Society and the Japan Geriatrics Society. Geriatrics and Gerontology International, 17(7), 1045-1047. https://doi.org/10.1111/ggi.13118 